\title{
Clinical evaluation in periodontitis patient after curettage
}

\author{
Widowati Witjaksono, ${ }^{*}$ Roselinda Abusamah,** and TP. Kannan*** \\ * Department of Periodontic, School of Dental Sciences University Science Malaysia and Faculty of Dentistry Airlangga University \\ ** DDS student, School of Dental Sciences University Science Malaysia \\ *** Department of Oral Biology, School of Dental Sciences University Science Malaysia
}

\begin{abstract}
Curettage is used in periodontics to scrap off the gingival wall of a periodontal pocket, and is needed to reduce loss of attachment (LOA) by developing new connective tissue attachment in patients with periodontitis. The purpose of this study was to evaluate the success of curettage by the formation of tissue attachment. This clinical experiment was done by comparing LOA before curettage, 2 weeks and 3 weeks after curettage on 30 teeth with the indication of curettage. Study population were periodontitis patient who attending dental clinic at Hospital University Science Malaysia (HUSM) with inclusion criteria good general health condition, 18 to 55 years old male or female and presented with pocket depth $\geq 3 \mathrm{~mm}$. The teeth were thoroughly scaling before intervention and evaluated by measuring the periodontal attachment before curettage, two weeks and three weeks after curettage. Repeated measure ANOVA and Paired T Test were used to analyze the data. The result of the study showed that there was reduction in the periodontal attachment loss in periodontitis patient after curettage either in the anterior or posterior teeth which were supported by statistical analysis. This study concluded that curettage could make reattachment of the tissue
\end{abstract}

Key words: loss of attachment, periodontitis, periodontal pocket

Correspondence: Widowati, Department of Periodontic, School of Dental Sciences University Science Malaysia, Health Campus 16150 K. Kerian, K. Bharu, Kelantan, Malaysia.

\section{INTRODUCTION}

Curettage is used in periodontics by scraping off the gingival wall of a periodontal pocket to separate the diseased soft tissue and remove the chronically inflammed granulation tissue formed in the lateral wall of the periodontal pocket. ${ }^{1,2}$ Curettage is needed to reduce loss of attachment (LOA) by developing new connective tissue attachment. $1,2,3$

There are so many opinions on curettage. Some investigators report that the removal of the pocket lining and junctional epithelium by curettage is not complete. ${ }^{4,5,6}$ However, other investigators report that both epithelial lining of the pocket and junctional epithelium, sometimes including underlying inflamed connective tissue, are removed by curettage. $1,3,7$

The reason why curettage no longer being frequently used, are because the procedure technically difficult to master and time consuming. ${ }^{3}$ Short and long-term clinical trials have confirmed that gingival curettage provides no additional benefit in terms of probing depth reduction, attachment gain, or inflammation reduction, ${ }^{8,9}$ when compared to scaling and root planning alone. Thus, some dental schools do not apply curettage in their daily practice activity. The American Dental Association has deleted curettage as a method of treatment on their 1989 World workshop in Clinical Periodontics. ${ }^{4}$ However, $80 \%$ of dental hygiene programs in the United States still apply the gingival curettage procedure with the reason that curettage is legally sanctioned duty in many states. ${ }^{10,11}$ Based on the controversions, the aim of the study was to evaluate the success of curettage by the formation of tissue attachment.

\section{MATERIALS AND METHODS}

This clinical experiment compared LOA before curettage, 2 weeks and 3 weeks after curettage. The samples were patients who visited HUSM dental clinic, in range of age 18 to 55 years old, general health in good condition, and suffered chronic periodontitis with periodontal pocket $\geq 3 \mathrm{~mm}$. The examinations were done on 30 teeth from 15 patients who match the criteria. Informed consent was obtained from all volunteers, and all procedures were in accordance to ethical guidelines established for human subjects which approved by the elective committee of University Science Malaysia, School of Dental Sciences.

The instruments were prepared and sterilized by dental surgery assistant including mouth mirror, tweezer, William probe, gracey curettes (Hu-Friedy), explorer, examination tray, gauze and cotton pellets. A week before curettage (0 day), whole mouth scaling and prophylaxis were done (Figure 1). Then, LOA evaluation was done at the same day and repeated at 2 weeks and 3 weeks after curettage. Loss of attachment was measured from the cemento enamel junction to the base of the pocket on the deepest site ${ }^{3}$ (Figure 2). After rinsing with 
chlorhexidine $0.2 \%$ solutions, local infiltrative anaesthesia was applied to the region of 13,14 and 15 (Figure 3). Then, removal of any soft and hard deposits from the root surface and also smoothening of the root surface (root planing) were done (Figure 4).

A universal curette was inserted inversely into the pocket. The inner surface of the pocket was carefully peeled (Figure 5a, 5b and 6a, 6b). Finally, the area was flushed with physiologic saline $0.9 \%$ to remove debris (Figure $7 \mathrm{a}, 7 \mathrm{~b}$ ), and the tissue was partly adapted to the

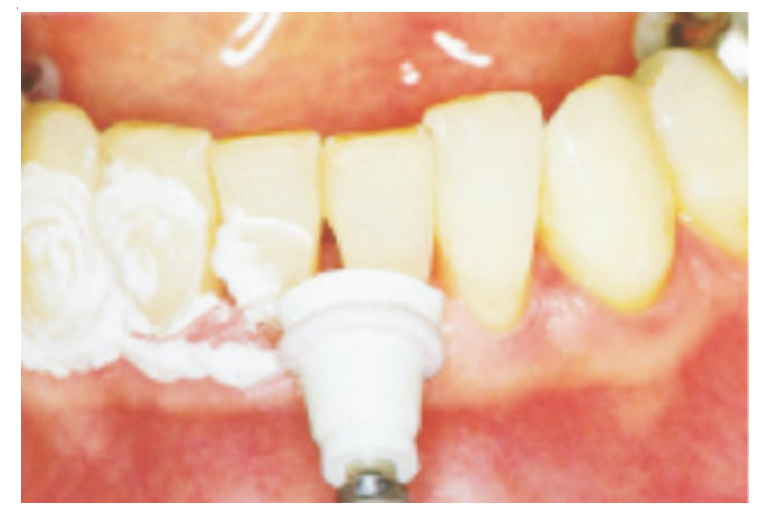

Figure 1. Scaling and prophylaxis a week before intervention (0 day).

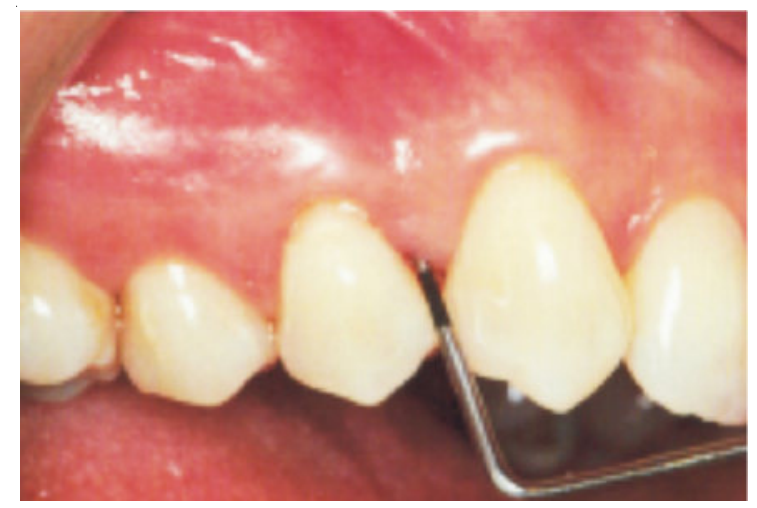

Figure 2. LOA measurement before curettage, 2 weeks and 3 weeks after curettage.

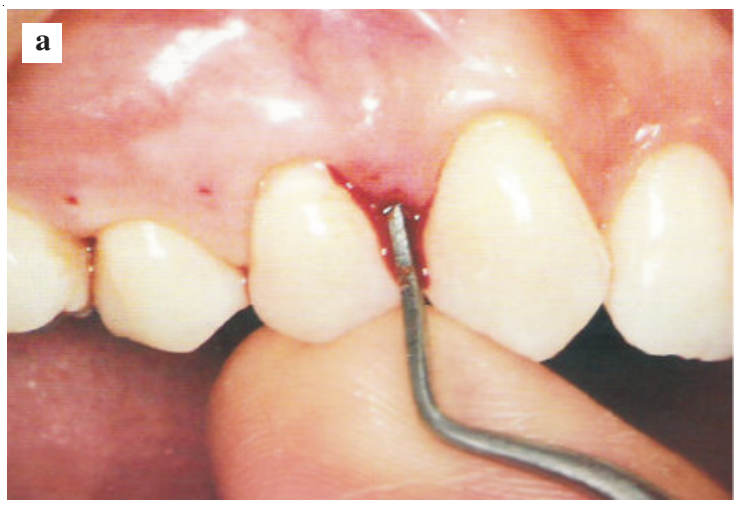

Figure 5a-b. Curettage on buccal site of 14 . tooth by gentle finger pressure. The clinical evaluations for periodontal attachment loss were repeated at 2 weeks and 3 weeks after curettage

\section{RESULTS}

Figure 8-a showed before curettage, the gingiva appeared hemorrhagic and bright red in the region 13, 14,15 . The normal conditions especially in color,

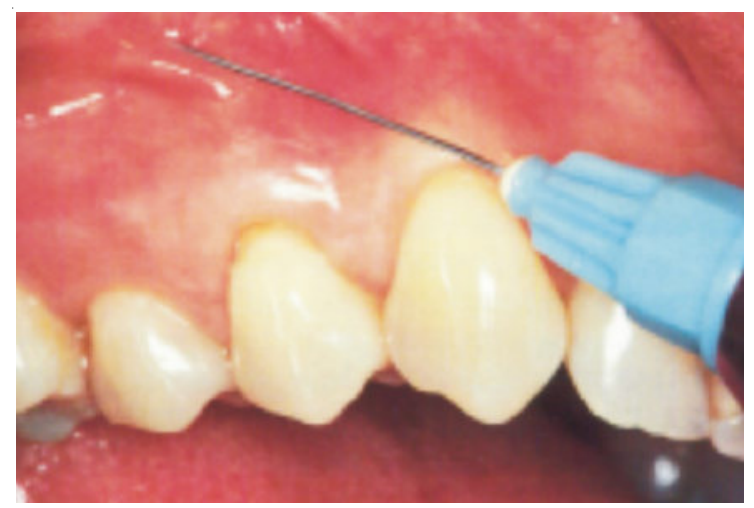

Figure 3. Local infiltrative anaesthesia.

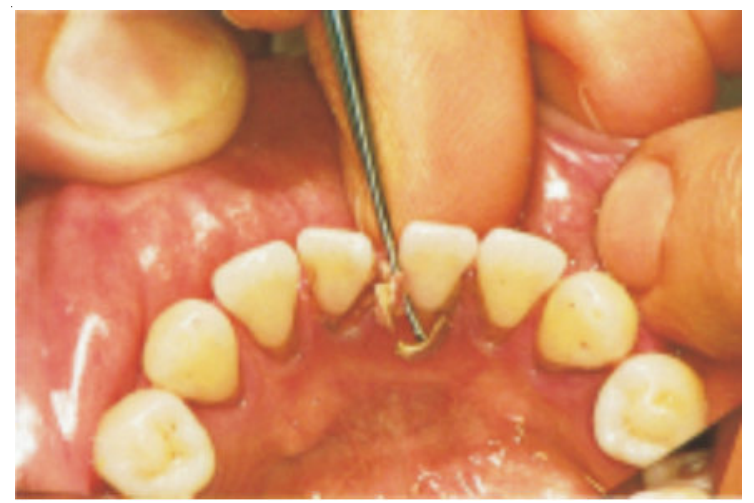

Figure 4. Scaling and root planing.

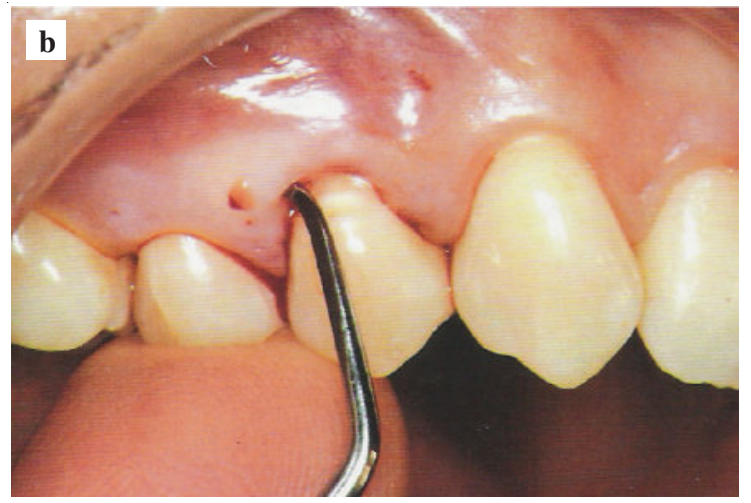



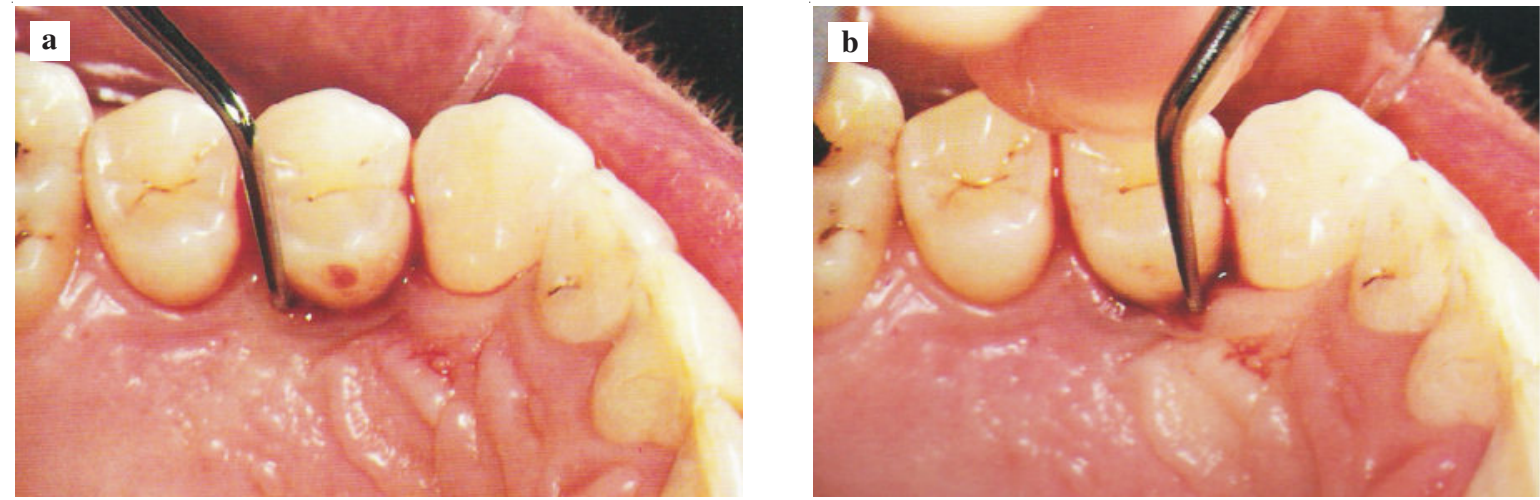

Figure 6a-b. Curettage on palatal site of 14 .
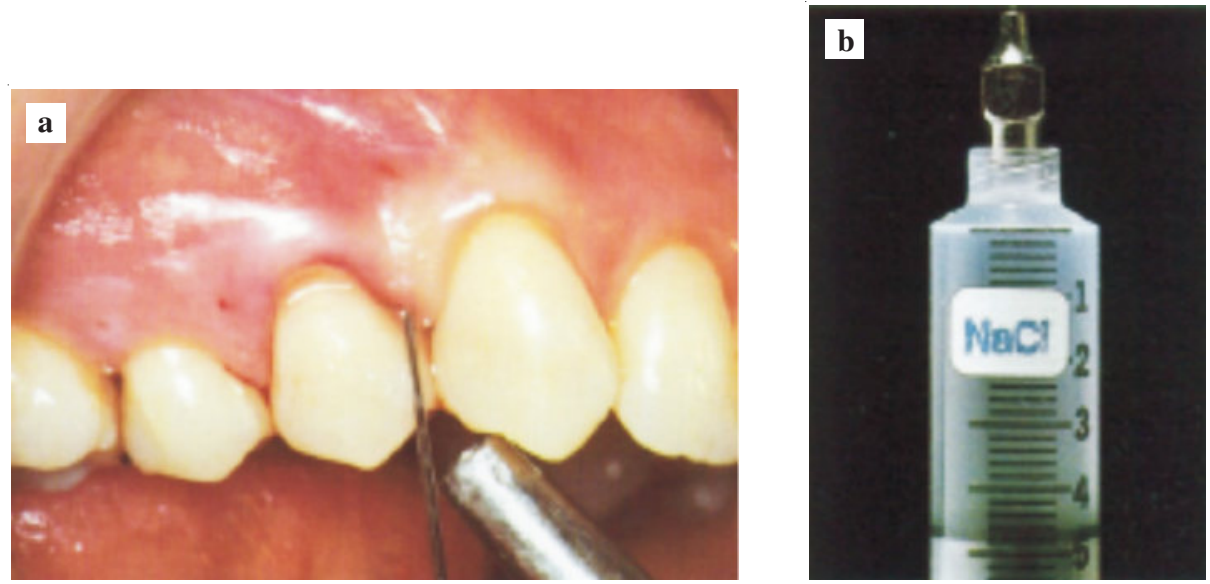

Figure 7a-b. Irrigation of pocket by $0.9 \%$ saline.
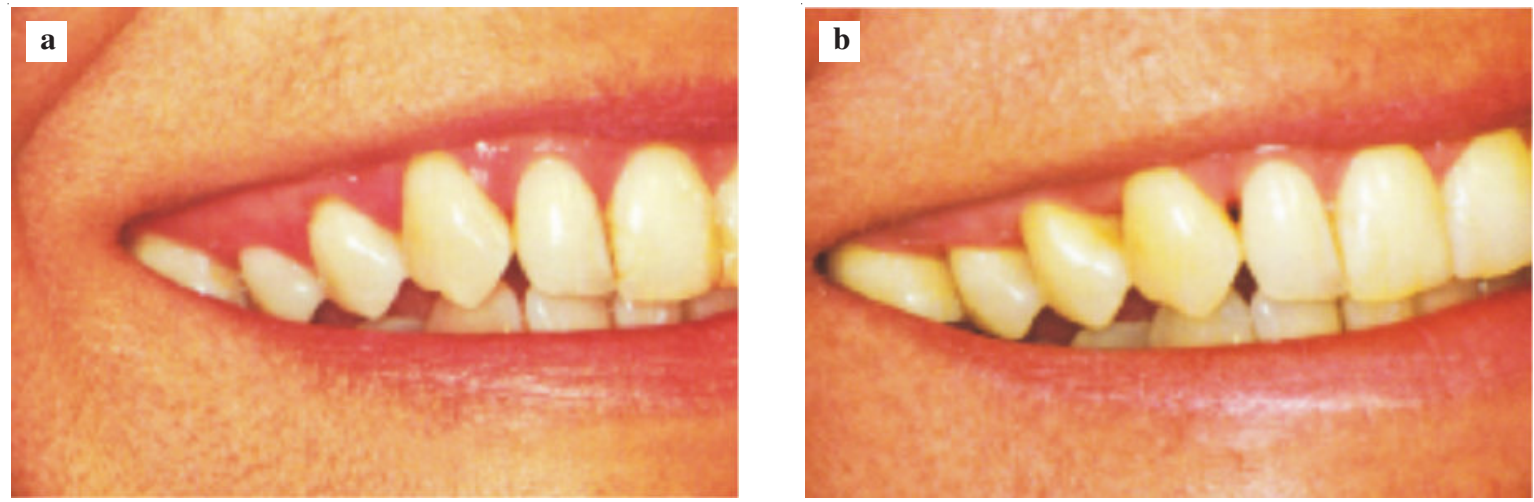

Figure 8. (a) Before curettage, (b) After curettage.

consistency, surface texture, and contour of the gingiva were attained at 3 weeks after curettage and the gingival margin was well adapted to the tooth (Figure 8-b). This result also can be interpreted on the Table 1.

Table 1 showed that all samples $(100 \%)$ were 30 cases with $\mathrm{LOA} \geq 3 \mathrm{~mm}$. Not a single had a LOA between 1 and $3 \mathrm{~mm}$. There were reduction from 30 cases to 26 cases within 2 weeks after curettage and to 10 cases within 3 weeks after curettage. Table 2 was showing LOA in the anterior and posterior teeth before curettage, 2 weeks and 3 weeks after curettage.

In the anterior region, 2 weeks after curettage the LOA $\geq 3 \mathrm{~mm}$ reduced from 10 cases to 8 cases and at 3 weeks after curettage reduced again from 8 cases to 4 cases. In the posterior region, 2 weeks after curettage the LOA $\geq 3 \mathrm{~mm}$ reduced from 20 cases to 18 cases and reduced 
Table 1. Loss of attachment before curettage, 2 weeks and 3 weeks after curettage (analyzed by repeated measure ANOVA)

\begin{tabular}{|c|c|c|c|}
\hline LOA Treatment & $\begin{array}{l}\text { Before } \\
\text { curettage }\end{array}$ & $\begin{array}{l}2 \text { weeks after } \\
\text { curettage }\end{array}$ & $\begin{array}{l}3 \text { weeks after } \\
\text { curettage }\end{array}$ \\
\hline $\mathrm{LOA} \geq 3 \mathrm{~mm}$ & $\begin{array}{c}30 \\
(100 \%)\end{array}$ & $\begin{array}{l}26 \\
(87 \%)\end{array}$ & $\begin{array}{l}10 \\
(33 \%)\end{array}$ \\
\hline
\end{tabular}

Table 2. Loss of attachment before curettage, 2 weeks and 3 weeks after curettage in the anterior and posterior teeth (analyzed by Paired T Test)

\begin{tabular}{lccc}
$\begin{array}{l}\text { Region } \\
\text { of LOA }\end{array}$ & $\begin{array}{c}\text { Treatment } \\
\text { curettage }\end{array}$ & $\begin{array}{c}2 \text { weeks after } \\
\text { curettage }\end{array}$ & $\begin{array}{c}\text { Beeks after } \\
\text { curettage }\end{array}$ \\
$\begin{array}{l}\text { Anterior } \\
\text { LOA } \geq 3 \mathrm{~mm}\end{array}$ & $\begin{array}{c}10 \\
(33 \%)\end{array}$ & $\begin{array}{c}8 \\
(27 \%)\end{array}$ & $\begin{array}{c}(13 \%) \\
\text { Posterior }\end{array}$ \\
LOA $\geq 3 \mathrm{~mm}$ & $\begin{array}{c}20 \\
(67 \%)\end{array}$ & $\begin{array}{c}18 \\
(60 \%)\end{array}$ & 6 \\
& & & $(20 \%)$ \\
\hline
\end{tabular}

again at 3 weeks after curettage to 6 cases. It showed that there was an increase of tissue attachment at 2 weeks and 3 weeks after curettage in the anterior and posterior teeth. Figure 9 showed that there was a significant reduction of LOA between before curettage and 2 weeks and 3 weeks after curettage. The reduction of LOA between before and after 2 to 3 weeks was more significant than the reduction between 2 weeks and 3 weeks after curettage.

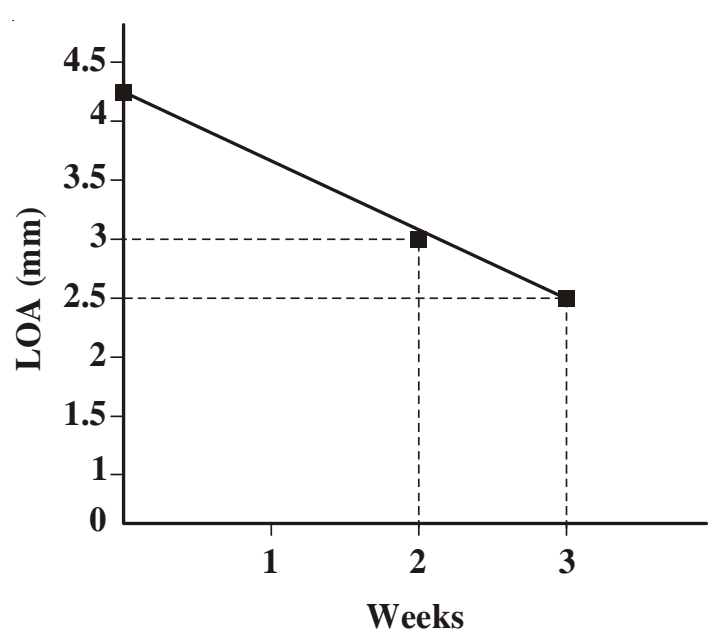

Figure 9. Loss of attachment (before, 2 weeks and 3 weeks after) curettage.

\section{DISCUSSION}

These clinical observations were done on the day of LOA measurement, 2 weeks and 3 weeks after curettage. The healing process was observed and professional plaque control were done during clinical examination and 3 weeks after intervention. This procedure was supported by the report which stated that healing of the epithelial lining of the pocket after periodontal debridement and gingival curettage can be expected to take 5 to 12 days ${ }^{11}$ while another study said that restoration and epithelization of the sulcus generally require from 2 to 7 days. ${ }^{1}$ From the clinical and statistical analysis, it showed that curettage could re-attach the tissue with reduction in LOA at 2 weeks and 3 weeks after curettage. According to the previous study, curettage could reduced pocket depth by developing new connective tissue attachment and tissue shrinkage. ${ }^{3}$ Other clinical study which also evaluate the effect of curettage in patients with periodontitis also concluded that curettage could make tissue re-attachment. ${ }^{12}$

This clinical experiment revealed that there were reduction in LOA after curettage in the anterior and posterior teeth. The statistical analysis showed that more reduction LOA obtained at before and 2 weeks after curettage as well as before and 3 weeks after curettage. However, less reduction from 2 weeks to 3 weeks after curettage may caused by several factors, such as short duration of observation (only a week), systemic factor or the immune status of the patient, and patients were not taking a good care of oral hygiene at home.

This condition was also supported by study that stated, if the area has not completely healed in 7 to 10 days, a disturbance in healing should be suspected. ${ }^{7}$ This is most commonly due to the presence of local irritants, either calculus that has not been removed or plaque that reaccumulated. ${ }^{2}$ If generalized delay in the healing of the entire curetted area occurs, a systemic interference should be suspected. ${ }^{13}$

The study revealed that periodontitis patient who undergone curettage procedure showing reduction of LOA clinically, either in the anterior or posterior teeth. Anyhow, the authors could support the American Academy of Periodontology statement ${ }^{4}$ to delete the curettage in the guidelines of periodontal therapy if the curettage was separated with scaling and prophylaxis procedure in periodontal treatment. In this study, curettage should always be preceded by scaling and prophylaxis which every body knows is the basic periodontal therapy, ${ }^{11,14}$ So there is no curettage can be done without scaling and prophylaxis.

This study showed that curettage could make tissue attachment by reduction of periodontal attachment loss. It means leaving or deleting curettage from the basic periodontal therapy should be aimed mainly to the mastered 
clinical periodontist since their hand skill in doing fully mechanical debridement. Finally, the authors would like to emphasize that although scaling, prophylaxis, and curettage are difficult, time-consuming and often tedious procedures, but they are basic to periodontal therapy and should be mastered by all general dental practitioners.

\section{ACKNOWLEDGEMENTS}

Curettage has not applied anymore on a daily clinical practice curriculum in the School of Dental Sciences University Science Malaysia. This procedures was conducted mainly for the purpose of elective project 2005-2006 as prerequisite for professional examination in the Doctor of Dental Surgery Course. Special thanks are extended to the dental surgery assistant's students who help much in running this project.

\section{REFERENCES}

1. Newman, Takei, Carranza. Carranza's clinical periodontology. $9^{\text {th }}$ ed. Philadelphia: WB Saunders Company; 2003. p. 744-47.

2. Simon $\mathrm{H}$. What are the procedures for treatment of periodontal disease? (cited 2002 December). Available at: http:www.umm.edu/patiented/articles/ what procedures treatment of periodontal disease $0000248 . \mathrm{htm}$. Accessed August 27, 2005.
3. Lindhe J, Karring T, Lang NP. Clinical periodontology and implant dentistry. $4^{\text {th }}$ ed. Oxford: Blackwell Publishing Company 2003; p. $406-08$.

4. American Academy of Periodontology Statement Regarding Gingival Curettage. J.Periodontol, October 2002, 73 (10): 1229-30. Available at: http://www.perio.org/resources_products/pdf/38_curettage.pdf. Accessed September 18, 2005.

5. Aukhil I. Biology of wound healing. Periodontology 2000; 2000. 22:44.

6. Cobb CM. Clinical significance of non-surgical periodontal therapy: An evidence-based perspective of scaling and root planing. J Clin Periodontol 2002; 29(Supplement 2):6.

7. Goldman HM, Cohen DW. Periodontal therapy. $6^{\text {th }}$ ed. St Louis, Missouri: The CV Mosby; 1980. p. 677-82, 760-61.

8. Greenwell H, Harris D, Pickman K, Burkart J, Parkins F, Myers T. Clinical evaluation of $\mathrm{Nd}$ : YAG laser curettage on periodontitis and periodontal pathogens. J Dent Res 1999; 78(Spec. Issue): 138 (Abstr. 2833).

9. Neil ME, Melloning JT. Clinical efficacy of the Nd:YAG laser for combination periodontal therapy. Pract Periodontics Aesthet Dent 1997; 9:1-5.

10. Perry, Beemsterboer, Taggart. Periodontology for the dental hygienist. $2^{\text {nd }}$ ed. Philadelphia: WB Saunders Company; 2001. p. 222-29.

11. Esther M, Wilkins. Clinical practice of the dental hygienenist. $9^{\text {th }}$ ed. Philadelphia: Lippincot Williams \& Wikins; 2005. p. 646.

12. Prahasanti C. Kehilangan perlekatan jaringan pada penderita periodontitis setelah dirawat kuretase. Maj. Ked. Gigi (Dent J.) 2001; 34(3a):199-201.

13. American Academy of Periodontology. Treatment of plaque-induced gingivitis, chronic periodontitis, and other clinical conditions. Endorsed by the American Academy of Pediatric Dentistry 2004; p.169-78.

14. Cohen ES. Atlas of cosmetic and reconstructive periodontal surgery. $2^{\text {nd }}$ ed. Boston Massachusets: Lea and Febiger; 1994. p. 222-29. 